\title{
A case of acute necrotizing pancreatitis complicated with non ST elevation myocardial infarction
}

\author{
Udaya Ralapanawa ${ }^{1 *}$, Thilak Jayalath ${ }^{1}$ and Dhanusha Senadhira ${ }^{2}$
}

\begin{abstract}
Background: Acute pancreatitis is an inflammatory condition with varying severity and a range of local and systemic complications. Here we report a patient with acute necrotizing pancreatitis complicated with a true non ST elevation myocardial infarction.

Case presentation: A 58 year old lady was admitted to our unit with acute onset epigastric pain and vomiting for $4 \mathrm{~h}$ duration. Following admission she complained of retrosternal tightening type of a chest pain. She had elevated serum amylase and cardiac troponin. Electrocardiogram (ECG) revealed lateral ischaemia. Contrast computerized tomography abdomen revealed acute severe necrotizing pancreatitis.

Conclusions: Nonspecific ECG changes can occur in patients with acute pancreatitis. But the diagnosis of true myocardial infarction in a context of acute pancreatitis using ECGs, 2D echocardiography, cardiac biomarkers and coronary angiograms can be challenging with the choice of revascularization therapy and safety of antiplatelet agents and anticoagulant therapy. Decision making regarding the management of such a patient is also critical.
\end{abstract}

Keywords: Acute pancreatitis, Myocardial infarction, 2D echocardiogram, ECG, Troponin I

\section{Background}

Acute pancreatitis is an inflammatory condition of pancreas which can range in severity from mild to severe disease. Most patients develop self-limiting disease but a minority of patients progress to a severe form with both systemic and local complications. Cardiovascular complications of acute pancreatitis include shock with systemic inflammatory response syndrome, hypovolemia, pericardial effusions and non-specific ST segment changes. Here we report a case of 58 year old lady who developed a non ST elevation myocardial infarction as a complication of acute necrotizing pancreatitis.

\section{Case presentation}

A 58 year old lady was admitted to our unit with acute onset epigastric pain and vomiting for $4 \mathrm{~h}$ duration. She is a diagnosed patient with type 2 diabetes mellitus

\footnotetext{
*Correspondence: udayapralapanawa@yahoo.com

${ }^{1}$ Faculty of Medicine, University of Peradeniya, Peradeniya, Sri Lanka

Full list of author information is available at the end of the article
}

for 10 years and hypertension for 5 years. Her diabetes was well controlled with HbA1c of 6 and without significant micro or macrovascular complications. She is a nonalcoholic. Following admission she complained of retrosternal tightening type of a chest pain suggestive of acute coronary syndrome. Pain was sudden onset, lasted for $20 \mathrm{~min}$ in moderate intensity and responded to the medications given in hospital. Physical examination revealed severe epigastric tenderness. There was no rebound tenderness. Cardiovascular and respiratory examinations were normal. She was haemodynamically stable with a blood pressure of $130 / 90 \mathrm{mmHg}$ and pulse rate of $96 \mathrm{bpm}$. 12 lead electrocardiogram (ECG) revealed $\mathrm{T}$ wave inversions in lateral leads including I, aVL, V5 and V6 (Fig. 1). Her serum troponin I titer was $14 \mathrm{ng} / \mathrm{mL}$ (normal less than $0.8 \mathrm{ng} / \mathrm{mL}$ ). $2 \mathrm{D}$ echo revealed lateral wall hypokinesia with preserved left ventricular function. Her serum amylase level on admission was $1741 \mathrm{U} / \mathrm{L}(20-115 \mathrm{U} / \mathrm{L})$. Contrast 


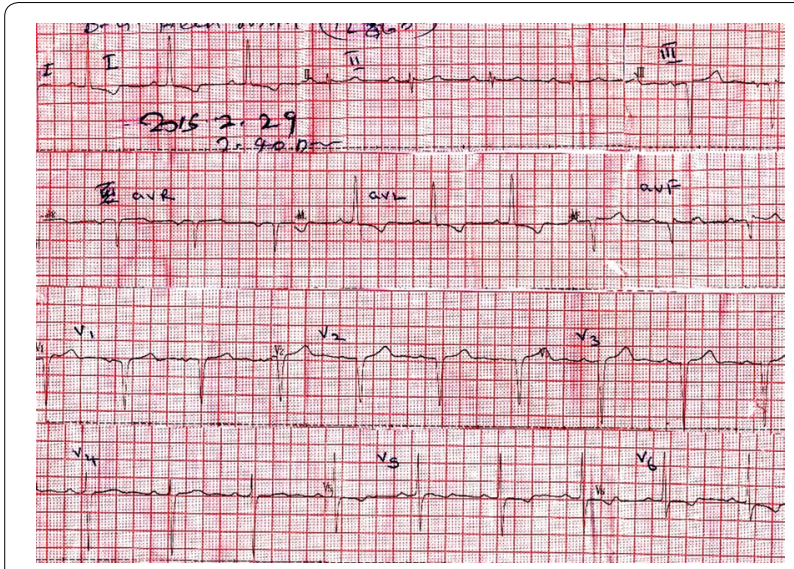

Fig. 112 lead ECG on admission

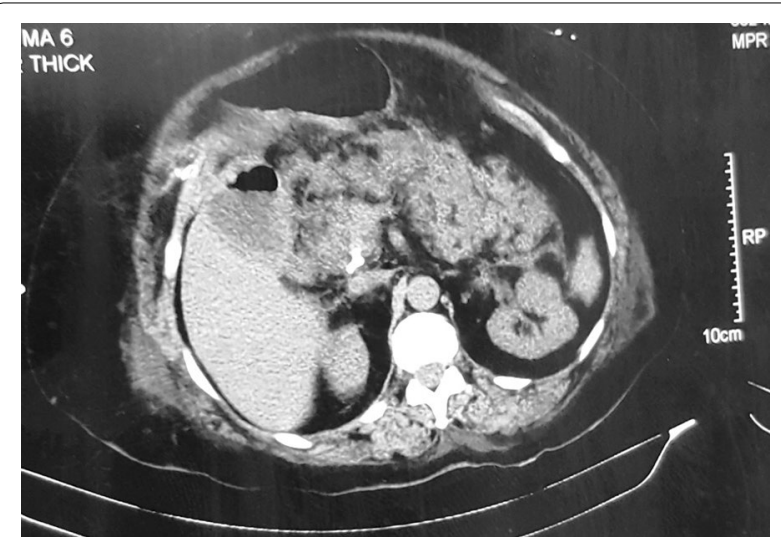

Fig. 2 CT abdomen showing necrotizing panceatitis

computerized tomography (CT) abdomen revealed acute severe necrotizing pancreatitis without pseudocyst formation (Fig. 2). Serum calcium, creatinine phosphokinase (CPK) and triglyceride levels were normal. Therefore she belongs to the moderately severe acute pancreatitis according to revised Atalanta criteria (2013). She was free of chest pain and haemodynamically stable following starting treatment with aspirin, clopidogrel, atorvastatin and nitroglycerin. Therefore she was given unfractionated heparin for $72 \mathrm{~h}$ and a coronary angiogram planned to be done later. Her serial ECGs showed minor dynamic $\mathrm{T}$ wave changes. She was given intensive care and improved during next few days with standard management protocol of acute pancreatitis. Three days later her repeat serum troponin level remained at $9.2 \mathrm{ng} / \mathrm{mL}$ and amylase level was $504 \mathrm{U} / \mathrm{L}$. A coronary angiogram was done after 2 weeks. It revealed minor coronary artery disease with only $20-30 \%$ stenosis at proximal left anterior descending artery.

\section{Discussion and conclusion}

Electrocardiographic changes are relatively common in acute pancreatitis. They include tachy and brady arrhythmias, conduction abnormalities including bundle branch blocks and changes in $\mathrm{T}$ wave and QT period [1]. These abnormalities are seen in approximately $50 \%$ of patients [2]. Experimental studies have reported that in acute pancreatitis there are myocardial ultra-structural disturbances including interstitial edema and cardiomyocyte hypoxia, myofibril over activity, intercellular oedema between cardiomyocytes and cardiomyocyte hypertrophy with collagenation of myocardial stroma [3, 4]. Elevated levels of cardiac troponins can be seen among patients with acute pancreatitis without true myocardial infarctions [5]. This can be attributable to rhabdomyolysis which is associated with acute pancreatitis [6]. In a study on the determination of myoglobin in acute pancreatitis patients has shown that $20 \%$ of acute pancreatitis patients had serum myoglobin concentrations above the upper normal limit [7].

Acute pancreatitis associated with true myocardial infarction is a rare incident and Kumara et al. [8] have reported such a true ST elevation myocardial infarction in a young patient with acute pancreatitis. In 2005, Krantzopoulos et al. [9] also have reported another case of myocardial infarction with acute pancreatitis. Diagnosis of acute myocardial infarction among patients with acute pancreatitis can be difficult. Erroneously administered thrombolytic therapy for pseudo myocardial infarction patients can have disastrous outcome. Cafri et al. [10] reported a 54 year old male who underwent thrombolytic therapy after being misdiagnosed with myocardial infarction. Precise mechanism of myocardial infarction in acute pancreatitis remains unclear. Hypothesized mechanisms for ECG changes and myocardial infarction include vagally mediated reflexes [11], metabolic and electrolyte abnormalities [12] toxic effect of pancreatic enzymes on myocardium, coronary artery spasm and prothrombotic derangement.

Above described patient's main presentation was acute pancreatitis. Also she is a known patient with type 2 diabetes mellitus and hypertension. In that context she has developed a true myocardial infarction as evidenced by high troponin I level and echocardiographic evidence of lateral wall hypokinesia. Although high troponin levels can occur with rhabdomyolysis among acute pancreatitis patients, this patient's CPK level was normal. We had no facilities to carry out an urgent coronary angiogram at 
Table 1 Summary of the recent literature review on cases with acute pancreatitis complicated with acute coronary syndrome (Source PubMed)

\begin{tabular}{|c|c|c|}
\hline Title & Authors & $\begin{array}{l}\text { Date } \\
\text { of publication }\end{array}$ \\
\hline Case series of pancreatitis with uncommon presentations & Redkar NN, Rawat KJ, Tiwari D, Panandikar G & 2015 \\
\hline $\begin{array}{l}\text { Acute pancreatitis complicated by acute myocardial infarction-a } \\
\text { rare association }\end{array}$ & Vasantha Kumar A, Mohan Reddy G, Anirudh Kumar A & 2013 \\
\hline $\begin{array}{l}\text { Acute pancreatitis complicated by ST-elevation myocardial infar } \\
\text { ction }\end{array}$ & Phadke MS, Punjabi P, Sharma S, Kide S, Nawale J, Chaurasia A & 2013 \\
\hline Myocardial infarction as complication of acute pancreatitis & $\begin{array}{l}\text { Asfalou I, Miftah F, Kendoussi M, Raissouni M, Benyass A, } \\
\text { Moustaghfir A, Zbir E, Hda A, Hamani A }\end{array}$ & 2011 \\
\hline $\begin{array}{l}\text { Acute necrotizing pancreatitis complicated with ST elevation } \\
\text { acute myocardial infarction: a case report and literature review }\end{array}$ & Hsu PC, Lin TH, Su HM, Lin ZY, Lai WT, Sheu SH & 2010 \\
\hline $\begin{array}{l}\text { Perplexing epigastric pain-coincident myocardial infarction and } \\
\text { acute pancreatitis }\end{array}$ & Wu CH, Wang KL, LuTM & 2010 \\
\hline $\begin{array}{l}\text { T-wave depletion and bradycardia possibly secondary to acute } \\
\text { pancreatitis: review of the literature }\end{array}$ & Türkay C, Aydoğan T, Karanfil A, Uyar ME, Selçoki Y, Kanbay M & 2009 \\
\hline $\begin{array}{l}\text { Deceived by acute pancreatitis masquerading as acute inferior } \\
\text { myocardial infarction }\end{array}$ & Low TT, Lee LC, Lee CH & 2009 \\
\hline $\begin{array}{l}\text { Emergency treatment succeeded in acute myocardial infarction } \\
\text { with acute pancreatitis and multi-organ failure: a case report }\end{array}$ & Chen X, Lu CZ, Li C & 2008 \\
\hline $\begin{array}{l}\text { Acute pancreatitis presenting as acute inferior wall ST-segment } \\
\text { elevations on electrocardiography }\end{array}$ & Makaryus AN, Adedeji O, Ali SK & 2008 \\
\hline Acute pancreatitis mimicking acute inferior myocardial infarction & $\begin{array}{l}\text { Tejada JG, Hernández F, Chimeno J, Alonso MA, Martin R, Bastante } \\
\text { T }\end{array}$ & 2008 \\
\hline $\begin{array}{l}\text { Acute pancreatitis mimicking acute myocardial infarction or vice } \\
\text { versa? An EKG case report }\end{array}$ & Makowska E, CzempikE & 2005 \\
\hline $\begin{array}{l}\text { ST-segment elevation pattern and myocardial injury induced by } \\
\text { acute pancreatitis }\end{array}$ & $\begin{array}{l}\text { Korantzopoulos P, Pappa E, Dimitroula V, Kountouris E, Karanikis P, } \\
\text { Patsouras D, Siogas K }\end{array}$ & 2005 \\
\hline
\end{tabular}

out Centre. Considering her haemodynamic stability and absence of ongoing chest pain we did coronary angiogram later and it revealed only $20-30 \%$ stenosis at proximal left anterior descending artery. Although she had risk factors for coronary artery disease, this episode of non ST elevation myocardial infarction cannot be attributable to atherosclerotic disease. That is because of her angiogram findings. Therefore most probably her non ST elevation myocardial infarction can be considered to be related with acute pancreatitis (Table 1).

Diagnosis of acute myocardial infarction in a context of acute pancreatitis is a challenging task. ECG changes and elevated cardiac troponins due to rhabdomyolysis can mislead towards the diagnosis of acute myocardial infarction. Subsequent treatment particularly with thrombolytic therapy can have disastrous out come in a patient with acute pancreatitis. In such a context an urgent coronary angiogram would have a pivotal role to decide on exact diagnosis and management. Management of such a patient is also challenging with the choice of revascularization therapy and safety of antiplatelet agents and anticoagulant therapy. Therefore these issues need further evaluation based on research and evidence.

\section{Abbreviations}

ECG: electrocardiogram; 2D-echo: 2 dimensional echocardiogram; CT: computerized tomography; CPK: creatinine phosphokinase.

\section{Authors' contributions}

Analysis and interpretation of patient data and literature review were done by UR, DS. UR, TJ guided the other authors in reporting this case and corrected the final manuscript. All authors were involved in the management of the patient. All authors read and approved the final manuscript.

\section{Author details}

${ }^{1}$ Faculty of Medicine, University of Peradeniya, Peradeniya, Sri Lanka. ${ }^{2}$ Teaching Hospital Peradeniya, Peradeniya, Sri Lanka.

\section{Acknowledgements}

We all express our gratitude to the patient, who kindly gave consent for her case to be presented in this paper.

\section{Competing interests}

The authors declare that they have no competing interests.

\section{Availability of data and materials}

Not applicable.

\section{Consent to publish}

Written informed consent was obtained from the patient for publication of this case report and any accompanying images.

Ethics approval and consent to participate Not applicable. 


\section{Funding}

Not applicable.

\section{Publisher's Note}

Springer Nature remains neutral with regard to jurisdictional claims in published maps and institutional affiliations.

Received: 19 September 2017 Accepted: 5 March 2018

Published online: 09 March 2018

\section{References}

1. Faintuch JJ, Abrahao MM, Giacaglia LR, Junqueria PC, Salgado LF. Electrocardiographic changes in pancreatitis. Arq Bras Cardiol. 1989;52(5):259-60.

2. Pezzilli R, Barakat B, Billi P, Bertaccini B. Electrocardiographic abnormalities in acute pancreatitis. Eur J Emerg Med. 1999;6(1):27-9.

3. Banks PA. Epidemiology, natural history, and predictors of disease outcome in acute and chronic pancreatitis. Gastrointest Endosc. 2002;56(6 suppl):S226-30

4. Saulea A, Costin S, Rotary V. Heart ultra-structure in experimental acute pancreatitis. Rom J Physiol. 1997;34(1-4):35-44.
5. Aundhakar SC, Mahajan SK, Agarwal AD, Mhaskar DM. Acute pancreatitis associated with elevated troponin levels: whether to trombolyse or not? Ann Med Health Sci Res. 2013;3(Supp 1):S50-2.

6. Pezzilli R, Barassi A, d'Eril GM. Cardiovascular alterations associated with acute pancreatitis. Pancreat Disord Ther. 2012;2:3.

7. Pezzilli R, Billi P, Barakat B, Cappelletti O, Miglio F. Rhabdomyolysis and acute pancreatitis. J Gastroenterol Hepatol. 1999:14:168-71.

8. Kumara AV, Reddy GM, Kumar AA. Acute pancreatitis complicated by acute myocardial infarction - a rare association. Indian Heart J. 2013;65(4):474-7

9. Korantzopoulos P, Pappa E, Dimitroula V. ST segment elevation pattern and myocardial injury induced by acute pancreatitis. Cardiology. 2005:103:128-30.

10. Cafri C, Basok A, Katz A. Thrombolytic therapy in acute pancreatitis presenting as acute myocardial infarction. Int J Cardiol. 1995;49:279-81.

11. Ro TK, Lang RM, Ward RP. Acute pancreatitis mimicking myocardial infarction: evaluation with myocardial contrast echocardiography. J Am Soc Echocardiogr. 2004;17:387-90.

12. Rubio-Tapia A, García-Leiva J, Asensio-Lafuente E, Robles-Díaz G, VargasVorácková F. Electrocardiographic abnormalities in patients with acute pancreatitis. J Clin Gastroenterol. 2005;39(9):815-8.

\section{Submit your next manuscript to BioMed Central and we will help you at every step:}

- We accept pre-submission inquiries

- Our selector tool helps you to find the most relevant journal

- We provide round the clock customer support

- Convenient online submission

- Thorough peer review

- Inclusion in PubMed and all major indexing services

- Maximum visibility for your research

Submit your manuscript at www.biomedcentral com/submit 